\title{
Factors Preventing in-service University English Language Teachers from Becoming Action Researchers in Pakistan
}

\author{
Hassan Syed \\ Sukkur IBA University \\ Correspondence concerning this article should be addressed to Hassan Syed, Sukkur IBA University, \\ Airport Road, Sukkur Sindh, Pakistan.E-mail: hassan.ali@iba-suk.edu.pkd
}

\begin{abstract}
Research suggests that TR enables classroom teachers to address their classroom-specific problems without having to rely too heavily on published research. However, despite the fact that TR narratives of language teachers have increased lately, there is still need for studies investigating the perceptions of university English language (EL) teachers about TR, and exploring the factors affecting their engagement with TR in culturally diverse contexts. The current study was designed to explore the perceptions of university EL practitioners about the factors that inhibit or encourage them to engage in TR in a university context in Pakistan. Data were obtained from fifteen EL teachers from four public sector universities through semi-structured interviews. Results show that teachers appeared to possess only simplistic knowledge of research as an activity aimed at finding something new. While a majority admitted to have done no research, even the engagement of others who claimed to have done some research seemed sporadic and less than systematic. The main factors responsible for teachers' dis-engagement from TR included academic culture, management's attitude, power relations between senior and junior faculty, workload, lack of monetary benefits, and large classes. A number of implications have also been discussed.
\end{abstract}

Keywords: teacher research, english language teaching, higher education, teacher education, education policy

\section{Introduction}

Teacher research (TR) is defined as a systematic, intentional and rigorous enquiry (individual or collaborative) conducted by teachers to address their classroom-specific issues (Borg \& Sanchez, 2015; Cochran-Smith \& Lytle, 1993). The idea of TR emerged in reaction to the traditional knowledge transmission models of education (Burns, 2005; Cochran-Smith \& Lytle, 1998), and the dependency of classroom teachers on professional research for solving classroom-specific pedagogical problems (Kasi, 2010). For over a decade there was little empirical evidence in the form of English language (EL) teachers' narratives regarding their engagement in research to believe in the transformational potential of TR in real-life classroom contexts. Lately, however, the sheer number of edited publications involving EL teachers' narratives and accounts of action research bears testimony to the increasing popularity and overwhelming reception of TR by classroom teachers in various contexts, for example, Japan, China, Turkey to name but a few (Borg \& Sanchez, 2015; Etherington \& Daubney, 2018; Levkina, 2018; Saglam \& Dikilitas, 2019; Slimani-Rolls, 2018; Suzuki, 2018).

Studies have shown that TR has the potential to empower EL teachers by developing their research skills, and help them become autonomous decision makers, consultants, curriculum developers, analysts and activists (Atay, 2008; Barkhuizen, Burns, Dikilitaş, \& Wyatt 2018; Cochran-Smith \& Lytle, 1998; Farreh \& Saeed, 2011; Kirkwood \& Christie, 2006; Macaro, 2003; Trent, 2010; Tuyan, 2018). Research has found multifarious factors that inspire or prevent teachers from engaging in TR, such as teachers' conceptions of research, and their willingness to solve students' problems, research skills, appropriate mentoring, collegial and organizational support, and access to research material (e.g. books and journals) (Borg, 2009; Magos, 2012; McDonough, 2006; Moore, 2011; Tien, 2010; Sanchez \& Borg, 2015). 
In the context of Pakistan, for example, while the government emphasises its commitment to promoting innovative research in higher education institutions (HEIs) (National Education Policy, 2017)1, anecdotal evidence suggests that most of the teachers hardly engage in TR to solve classroom-specific problems. According to a report by British Council (2018) on the research culture in the HEIs in Pakistan, some of the senior EL faculty with research skills consider research to be a solitary activity and a number game; they conduct research for their career growth, i.e. promotion and other incentives. Conversely, encumbered with teaching workload the junior EL faculty with little knowledge of TR and lack of research skills in general seem to consider research to be unrewarding because faculty promotions in higher education are subject to Mphil and $\mathrm{PhD}$ rather than research productivity ${ }^{2}$ (Halai, 2011; Khan, Shah, \& Khan, 2018). They are, therefore, more concerned about coping with their teaching workload and dealing with exam-oriented education system as well as improving their qualifications. In addition to that, despite 300 teacher training resource centers, 279 pre-service and inservice training institutions in the country, out of which 68 are in Sindh province alone (Coleman, 20103; Halai, 2015), the obsolete pre-service training structure and...less than adequate in-service training regime with only limited or no TR training is also one of the major stumbling blocks to TR in Pakistan (National Education Policy, 2017).

Although recently a few teacher education institutions in Pakistan have introduced TR in their degree programmes, it is by no means the case in teacher training programmes in general (Halai, 2011; Shamim, 2008). What is even more worrisome is that there are only few studies reflecting upon the current state of the challenges EL teachers face in conducting classroom research in the higher education in Pakistan. The ones that are available are rather dated (Halai, 2011; Kasi, 2007; Shamim, 1996), and focus mainly on primary and/or secondary school teachers in urban areas, e.g. Karachi (Shamim, 1996). Thus, the potential of TR by teachers engaged in English language pedagogy still remains under-exploited in the context of Pakistan. Therefore, there is a need for more context-specific studies into factors affecting teachers' research engagement in higher education in order to make teaching a research-informed practice in Pakistan. The present study, therefore, aims to contribute to literature by exploring factors affecting EL teachers' engagement in TR in higher education in Pakistan.

\section{Factors Influencing Teachers' Engagement in Classroom Research (CR)}

Research suggests that a number of factors, such as professional, cognitive, attitudinal, technical, logistic and others, contribute to teachers' willingness or unwillingness to conduct teacher research (Sanchez \& Borg, 2015). Professional development, promotion and employer expectations have been reported as the most important factors that motivate teachers to do research in their own classrooms (Atay, 2008; Borg, 2007; 2009; McDonough, 2006; Wyatt, 2011). For instance, MCDonough (2006) investigated the experiences of graduate teaching assistants' (TAs) experiences of conducting action research in a second and foreign language teaching context. The results showed that participants reported that they developed a better understanding of research and insights into language teaching practices inside the classroom.

More recently, Tuyan (2018) conducted a study with seven instructor mentees involved in action research in a Turkish context. Based on a survey, the study showed that participants engaged in action research experienced professional development, developed understanding of research and sensitivity to students' problems, and understood the significance of collaboration. The study argued that teachers' motivation to remain engaged in TR is associated with professional gains, a sense of enjoyment in critical self-reflection, and self-empowerment. It is also noteworthy that teachers' engagement with classroom research also depends on their expectations of types of rewards and their personal disposition regarding how they perceive their professional development (Worral, 2004; Tien, 2000). For example, Worral (2004) conducted a study into school teachers' perceptions regarding the impact of TR on their professional development. Participants in the study reported that research engagement for them proved to be unrewarding as it failed to have any significant impact on their teaching practices.

Besides, TR faces enormous challenges including teachers' conceptions of research, attitudinal factors, such as management's attitude, lack of mentoring and collegial support, technical factors, for instance, lack of research

\footnotetext{
${ }^{1}$ National Education Policy (2017). Government of Pakistan, Ministry of Education, Islamabad. https://planipolis.iiep.unesco.org/sites/ planipolis/files/ressources/pakistan_national_education_policy_2017-2025.pdf

2 British Council of Pakistan (2018). The university research system in Pakistan. https://www.britishcouncil.pk/sites/default/files/the_university_research_system_in_pakistan.pdf

3 Coleman, H. (2010). Teaching and Learning in Pakistan: The Role of Language in Education. The British Council. https:// www.britishcouncil.org/pakistan-ette-english-language-report.pdf
} 
skills, and other factors, including lack of time have been reported to have a debilitating effect on TR. The main cognitive barriers involve teachers' positivist conceptions of research, the dichotomy between teaching and research, and the myth that good teachers do not have questions (Cochran-Smith \& Lytle, 1992; Macaro, 2003; McDonough, 2006; Schapper \& Mayson, 2010). Research has shown that a majority of teachers subscribe to a somewhat positivistic research paradigm considering objectivity, hypothesis, statistics and generalizability as the main criteria of good quality research (Borg, 2007; 2009; Shkedi, 1998). They consider research to be a highly complicated and technical activity (McDonough, 2006). For example, Borg (2009) conducted a study into EL teachers' conceptions of research and factors influencing their research into classroom-specific issues. The data was collected from a cross section of EL teachers $(n=505)$ of varying qualifications and language teaching experiences from across the world. Results showed that participants' definition of research included tests, experiments, peer-observations, and publications as essential elements. Thus, teachers' positivistic notions about research were the main hurdles preventing them from TR.

Furthermore, research has also shown that management's attitude, lack of research skills, and lack of time as some of the recurrent factors hindering TR. For instance, research shows that management's attitude has a strong bearing on teachers' engagement in CR (Allison \& Carey, 2007; Borg \& Alshumaimeri, 2012; Worral, 2004; Xie, 2015). However, the role of management varies from context to context: In some contexts management was encouraging but not supporting; in other contexts the management was encouraging and supporting teachers to do research, while in yet other contexts it was neither encouraging nor supporting it (Allison \& Carey, 2007; Borg \& Alshumaimeri, 2012; Everton, Galton, \& Pell, 2000; Taylor, 2007; Worral, 2004). For instance, Taylor's (2007) study examined the perceptions of both teachers and management of four universities in England and Sweden. The study revealed that the management and policy making staff in all the four universities had a firm belief that teaching and research are intertwined and the nexus between teaching and research is beneficial for teachers as well as the institution. On the contrary, in a study conducted by Borg and Alshumaimeri (2012) with teacher educators in a university context in Saudi Arabia, an overwhelming majority (i.e. 79.3\%) reported that while their management expected them to do research, it did not offer any material or moral support to the teachers interested in Classroom Research. in some contexts management's expectations were reported to have a low impact on TR (Borg, 2009), while a relatively high impact in other contexts.

Similarly, lack of research skills, and mentoring, also emerged as the most commonly cited constraints in TR (Anderson \& Herr, 1999; Atay, 2008; Xie, 2015). Xie (2015), for instance, conducted a TR project with a purpose to enhance second language learners' motivation to attend her classes. According to her, the main hindrances she experienced while doing TR involved a lack of knowledge and research skills; lack of mentoring and support from colleagues; and pressure from exam-oriented educational system. Based on her experiences, she argued that in order for TR to thrive, the teacher-researchers should be encouraged to work together, and receive adequate moral and technical support from the management. Additionally, a lack of time, and pressure from children's parents have also been cited for teachers' disengagement from TR (Atay, 2008; Gow \& Chow, 2012). For example, Atay's (2008) study into English language teachers $(n=62)$ in a university in Turkey reported excessive workload (between 18 and 21 hours), and consequently, lack of time to be the two main reasons for teachers' disengagement from TR.

Most notably, the teachers blamed management for having no 'release time or support' to do research (Christenson et al., 2002). Some studies reported that teachers did not do research because there was no institutional pressure on them to do so (Allison \& Carey, 2007; Worral, 2004). Additionally, the pressure from students' parents also affects teachers' motivation to engage in TR. For example, Magos' (2012) study into TR in Greece found students' age and stress caused by students' parents as the main factors preventing TR. The stress caused by parents' intervention in teachers' work did not allow them to engage in TR.

Studies into TR in Pakistan have also reported a host of factors that prevent affect teachers' intentions to do TR, such as lack of research skills, large classes, institutional expectations, and teachers' perceptions of research, and the pressure on teachers for the completion of the syllabus (Halai, 2011; Kasi, 2010; Sarwar, 2001; Nadeem, 2011). For instance, Halai (2011) conducted a qualitative meta-synthesis of studies into TR in a university context in Pakistan. The study showed that TR is widely regarded by practitioners as messy, tedious and time consuming. The study also highlighted management negatively affected teachers' willingness to engage in TR by forcing them to choose between the role of teacher and researcher, and invest their energy and time on getting their students to score higher marks in the board exams. 
Notwithstanding its benefits, TR has faced criticism on account of lacking validity and reliability. This line of argument holds that research conducted by teachers in highly specific settings on a relatively smaller scale involving a small number of students/respondents tends to be subjective, circumstantial and pedagogically ineffectual since it fails to ensure generalisability (Burns, 2005; Cochran-Smith \& Lytle, 1998). It is argued that if TR is to be regarded as research, it must be quantitative, naturalistic, value-free, and objective. In contrast to that, others adopt a constructivist and interpretivist perspective considering TR to be inherently subjective, interpretive and context-bound inquiry. According to them, TR has its own procedures of validity, that is, instead of internal/external validity, reliability and objectivity, it works with credibility, transferability, and conformability (Dornyei, 2007; Kirkwood \& Christie, 2006). Thus, making positivist demands on TR, especially when TR does not subscribe to or claim to follow it, is unrealistic and unjustified (Borg \& Sanchez, 2015).

The review of literature illustrates that while TR is beneficial for teachers' professional and personal development, it faces numerous challenges, including teachers' misconception regarding TR being too technical and statistical, as well as the dichotomous relationship between teaching and research (Allwright, 2005); management's discouraging attitude; lack of mentoring and research skills; and lack of time (Borg, 2009; Wyatt, 2011). What is conspicuously missing in the literature is a discussion on the role and nature of research culture prevalent in academia. Given the complexity and specificity of each classroom context, and TR being an attempt at understanding and solving classroom-specific issues, more context-specific studies are needed to reveal the challenges faced by TR in other contexts. In Borg's (2006) words, 'if teacher research is to become an integral part of teachers' professional practices, then it needs to extend beyond such settings and purposes' (p. 23). The present study, therefore, aims to explore the perceptions of English language teachers about the factors which influence TR in Pakistan. The main questions this study aims to investigate are:

\section{Research Questions}

RQ 1 What are the perceptions of in-service university English language teachers about classroom research in Sindh Pakistan?

RQ 2 What are the factors which influence in-service university English language teachers to do research in their own classrooms in Sindh Pakistan?

\section{Method}

\section{Context and Participants}

The study was conducted in four public sector universities in the Sindh province of Pakistan. Sindh offered a fertile ground for obtaining data due to a significant number of universities in the province $(n=47)$ including 17 public and 30 private universities. Moreover, it was due to lack of time and financial resources, and access to research participants were the main reasons the present study was not conducted in any other province. Since I belong to Sindh province, moving from Sindh to any other province involved financial and contextual challenges. For instance, living in a different province for the period of data collection might involve unforeseen expenses. Secondly, due to lack of familiarity with participants, obtaining consent from institutions and the English language teachers for participating in the study could be another challenge overcoming which could take a long time and resources. However, since I had been a teacher in English in various universities of the Sindh province, it was relatively easier for me to get access to the participants personally, or through common friends and acquaintances. Thus, emails for participation in the study were sent to the English faculty of four $(n=4)$ public sector universities of the Sindh province of Pakistan.

Most importantly, since the aim of the study was to understand the perceptions of English language teachers serving in university, participants were recruited using purposive and convenience sampling. EL teachers of four local universities were invited by email to participate in the study. However, due to low response from the population, personal and friends' contacts were used to get the interviews with teachers. Initially, I approached the teachers I had worked with in the past since they were less likely to conceal any information with regard to their engagement in research, attitude of faculty members and management. It was seemingly difficult to get the data from teachers who were not familiar with me personally. There were chances that some of the participants 
might not agree to reveal their thoughts and experiences of TR. Therefore, friends' contacts and references were used to reach out to teachers from Uni-3 (Newby, 2010). Detailed information about participants is given in Appendix-1.

Fifteen EL teachers from four universities volunteered to participate in the study. Three types of faculty participated in the current study: Permanent faculty with more than 10 years of language teaching experience at a university (henceforth senior faculty); permanent faculty with less than 8 years of teaching experience at a university (henceforth junior faculty with a permanent job)' and faculty working on a contract basis (henceforth junior faculty on a contract). There were significant differences in the privileges and workload of the different types of faculty. Senior faculty received higher salary and relatively less teaching workload; while the junior permanent faculty received better salary compared to those on a contract, their amount of workload was not much different from contractual faculty; lastly, the junior faculty on contract were given relatively higher workload but paid significantly lower amount for their services than the permanent junior faculty.

Six of the participants (i.e. T1, T2, T3, T4, T5, T6) were from a public sector university (henceforth Uni-1) in the Khairpur region of the province. Uni- 1 offers undergraduate and postgraduate courses in arts, sciences, and business. The English department of this university offers courses in both literature and linguistics to undergraduate and postgraduate students. The department had a total of fifteen faculty members, including five permanent teachers, including four senior faculty and one junior faculty, while others were on contract teachers whose contract was renewed every six months. Two of the senior faculty possessed $\mathrm{PhD}$ in linguistics, seven had a master of arts (MA) in literature, while the rest held an MA in linguistics. The linguistics faculty taught courses, including introduction to linguistics, introduction to second language acquisition, psycholinguistics, and sociolinguistics. The teachers in English literature taught courses, such as English drama, classical poetry, English prose, etc. Most notably, the permanent faculty, including both senior and junior, enjoyed job security, got regular promotions, and received government salaries with perks and benefits, while the contractual teachers received only a quarter of what the former were taking in salary, with no job security or promotions, and no perks and benefits.

Five of the participants (i.e. T7, T8, T9, T10, T11) belonged to another public university (henceforth Uni2), located in the Sukkur region of Sindh province, offered both undergraduate and postgraduate courses in business, education, engineering, computer science and maths. The faculty comprised of seven teachers of different age, qualifications and experiences of which only five consented to interview. Since the university did not offer courses in linguistics or literature, the various courses that the English faculty taught, included Functional English, Creative writing, Business communication, across all the departments. All the teachers of Uni-2 were permanent faculty members. This was a well resourced university with sufficient public and private sector funding to provide students with scholarships and running various talent hunt programs for candidates aspiring to study at the university. The English faculty taught regular courses in the morning and extra classes in the evening for the purpose of increasing their income.

Three participants (i.e. T12, T13, T14) were associated with a university (henceforth Uni-3) located in Hyderabad region of Sindh. The university was one of the largest universities of the province offering a variety of courses in a wide range of disciplines, including the sciences, arts, business, computers and engineering. English faculty of Uni-3 is comprised of more than twenty teachers of varying age groups, qualifications and experience. EL teachers at Uni-3 taught a list of similar courses as the teachers in Uni-1. One of the participants (T15) was also from an Engineering university (Uni-4) in the Nawabshah region of the Sindh province. The university offered undergraduate and postgraduate courses in disciplines, including Civil, Mechanical, and Electrical Engineering. The list of English courses that the faculty taught was very similar to the list of courses in Uni-2.

\section{Data Collection: Interviews}

Semi-structured interviews were conducted in order to elicit participants' responses regarding the factors affecting their TR. The interview guide comprised of open-ended questions and was divided into three main sections: The first section consisted of questions related to the personal information of the participants/ interviewees; i.e., their age, qualifications and experience; second section comprised of some general questions about their perceptions of research and whether they read published research and conduct any TR; third section involved questions about the factors that encouraged or discouraged them to engage in TR. Interviewees were 
free to answer in as much detail as they like. Some of the participants $(n=12)$ agreed to a face-to-face interview, while others (T13, T14, T15) preferred to send their responses via email. Their responses were followed up through the phone later. Participants were given the choice to opt for mother tongue (Sindhi or Urdu) or English to respond to interview questions. Ten participants agreed to do the interview in their native language (Sindhi), while the rest of them (T1, T7, T12, T13, T14) voluntarily responded to questions using English. Interviews in Sindhi were translated into English and transcribed with the help of a lecturer in English and a colleague.

\section{Data Analysis}

The data obtained in the form of transcripts and e-mails were constantly read and analysed during data collection. The type of analysis of the data was interpretivist: based on the examination of the participants' responses. The data from each participant was read iteratively to examine teachers' perceptions and analysed under the given themes, i.e. teachers' conceptions and practices of research, and secondly, the factors influencing TR.

The categories adopted lied on a continuum between deductive and inductive categories. Deductive categories, such as teachers' positivist conception of research, binary between the roles of teacher and researcher; lack of research skills; lack of time; and management's' attitude, were derived from literature, while inductive categories, such as attitude of senior faculty and large classes, emerged through content analysis and constant comparison approach. Part of the data was independently coded and compared by a colleague in the same institution. Coding agreement (90\%) was achieved using: number of agreement/total number of agreementsdisagreements. Findings of the study are presented in the next section.

\section{Results}

\section{Teachers' Conception of Research}

The data show that the majority of participants considered research to be a process of 'finding' something, while others described research as something which explores something new'; yet others said, it is a kind of discovery which finds something 'that already exists'. For instance, T1 said, 'when we explore something, when we put all our efforts to prove or disprove something'.

Some indicated a lack of confidence in defining research. T8, for instance, stated 'to find out something, right [my italics]!? Something that already exists but we research it, find it out'. The word in italics (i.e. right) in the response of T8 indicates her lack of confidence in her definition of research as she seemed to be trying to confirm definition from the interviewer. Some of the participants gave somewhat elaborate and specific answers which gives an impression of their familiarity with research. For example, T2 described research as something which 'explores a problem or a question in a particular area and tries to find out answers, which can be used for practical purposes and benefits. Or at least finds basis for future explorations'.

This definition not only defines what research is but also suggests the practical purpose it is carried out for. T6 gave an even more elaborate definition describing it as an organised activity which serves a variety of purposes besides discovering facts, i.e. proving or disproving a hypothesis, devising a line of action for practitioners in the light of facts. In T6's own words, 'research is an organized study or investigation into a subject in order to discover facts, to establish or revise a theory, or to develop a plan of action based on the facts discovered'. T10 called it a 'conscious inquiry' for solving [classroom-specific] problems. In defining research, T3 made an attempt to illustrate the difference between 'natural science research' and 'social science research'. He said:

Scientific research requires a lot of physical things, like if somebody is a patient of tuberculosis so there has to be some virus or some bacteria that needs to be identified. In social sciences we don't have such a luxury. In social sciences it is more cooperative and behavioural. Otherwise in scientific research that is happening in chemistry $u$ need to be finding some matters and putting the things together and finally getting some results. But we cannot in social sciences get things like that (T3).

According to this statement, research in natural science and social science diverges: the former deals with something concrete (i.e. tuberculosis, bacteria), finds out facts and puts them together, whereas, the social 
science deals with abstract issues related to behaviours and opinions of people. The complexity of this definition is to some extent emblematic of teachers' understanding of research, and the complexity teachers unconsciously attribute to the activity of research.

\section{Teachers' Practice of TR}

Furthermore, when they were asked whether they themselves do any research in their own classrooms, two participants (T10, T14) did not respond to the questions, eight participants (T2, T3, T5, T6, T7, T10, T11,T13) said they do not do it, while five (T1, T4, T8, T9, T12) said they do only 'sometimes'. For example, T1 said while he 'keeps thinking' about finding innovative ways to solve students' problems, he does not engage in classroom research. T8 also said he keeps observing her students and sincerely tries to solve students' problems regarding language learning. T9 reported that he did research to improve students' oral communication in the past wherein he tried to develop strategies to develop students' fluency.

I interviewed some students once in order to learn what I could do to improve their L2 fluency. But that was a year ago. (T9)

T12, however, seemed to be relatively more skilled in research. He claimed to have conducted research into motivation for reading in L2 using Vygotskian sociocultural theory. It suggests that T12 was familiar with research skills; however, his research was conducted as an obligation for passing his master degree rather than for solving classroom-specific issues. T12 stated, 'Yes, I have conducted research on students' motivation, and on devising strategies to enhance their zone of proximal development in improving reading'.

\section{Factors Affecting Teachers' TR}

Various factors were found to have a bearing on teachers' research activity, of which two factors emerged to be the main ones: teachers' concern about solving students' problems, and their professional development as teachers. For example, T1 said he does TR because it would bring him as well as his institution 'a good name'. T4 and T6 said they do it because they are concerned about their own and their students' improvement. T5 said he has been doing it for improving his students' 'fluency level', as well as for saving himself from stagnation as a teacher. T7 does it for motivating his students to give 'oral presentations'. T8 said she does it solely for her students' better performance. T9 gave various reasons for doing research, i.e. 'solving students' problems', 'conveying the message properly', 'becoming a successful teacher' and 'increasing [his] confidence'. T10 said he investigates the problems of his students because he is 'also a part of teaching and learning processes'. Following excerpts summarise the responses of the participants:

I started to dig out the truth as to why my students feel hesitation to give oral presentation? Is dice [rostrum] a snake or a scorpion? Why is it that only a few students turn up on the day presentations are scheduled? (T7)

...it is just because of my commitment to my students, with my job. This extra work [research] on the part of the teacher will give him and his institution a good name. (T1)

\section{Academic Culture}

Majority of the participants reported that the main reason, amongst many others, for their not involving in research was due to academic culture. By academic culture they meant the routine practices and discourse within the department. Participants reported that teachers mostly discuss the tangible advantages for any activity beyond their routine workload. As T1, himself a senior faculty member, reported,

We [teachers] talk about monetary benefits and packages that we will get for doing research. The intellectual benefits of research are not discussed.

Some of the teachers' comments were a bit blunt. For instance, T2 said, 'academic culture discourages not only from doing research but also from conducting classes'. T7 reported that, 'the culture is such that you come to university, conduct class, talk drivel, kill time and leave'. Similarly, T12 and T13 reported that research is not even discussed in their university; what is discussed is 'politics'. For instance, T13 stated that most of the teachers are busy 'lobbying, playing foul against the opposite groups'. Discussing the academic culture in his 
institution, T6 indicated towards lack of research activity even amongst the senior faculty as a discouraging factor. He stated, 'we don't do research because we don't see even the senior faculty do it'.

\section{Attitude of the Senior Faculty}

Some of the participants also referred to the non-supportive attitude of senior faculty with more work experience, research skills and qualifications, as the main stumbling block to TR. Participants reported that the lack of cooperation and help on the part of senior and highly qualified, i.e. $\mathrm{PhD}$, faculty also discouraged the junior faculty to do research. For instance, T5 reported,

Young teachers are full of spirit and enthusiasm for performing their jobs even if they try to go into the depth of the problem but the attitude of seniors with juniors is not supporting and encouraging, they just treat the juniors like slaves.

Responses of some of the senior faculty also bear witness to the non-cooperative attitude of their peers. For example, T1 reported that senior faculty does not support junior faculty in TR because they are afraid of losing their authority that the seniors have by virtue of possessing research skills,

I have always found them in a state of fear, if they shared their research with juniors, they would lose their position in the department. And the authority senior teachers have been enjoying for many years so they don't want to share their authority (T1).

The comprehensive response above indicates the insecurities of the qualified and skilled senior teachers and the power relations between senior and junior faculty.

\section{Management's Attitude}

Participants also reported that management's attitude also exerted a strong impact on their engagement with research. Management expected teachers to be engaged in classroom teaching, assessment and administrative jobs rather than research. Also, management maintained a strict distinction between teaching and research. For example, T13 reported, 'management is the problem; it discourages you; it forces you to quit the idea of research'. And T5, replied as, 'the role of the heads of the department regarding this (research) is not supportive'. T15 told a similar story with regard to research in his institution, 'management is concerned about syllabus, exams and tests in our universities rather than research'.

The responses of some of the participants were inconsistent regarding management's attitude. For example, T7 and T9 said that the senior faculty is supportive, and the management facilitates research. However, T11 stated that management 'is not pro-research'. Most interestingly, while T8 also admitted that management was not research friendly, he held the teachers responsible for indifference towards TR. In his words, 'the management does not favour research but somehow we are also responsible for not doing it'. He also admitted that teachers do not find time to do research because on the one hand they have to do excessive teaching, and on the other hand, the management involves them in administrative jobs, such as coordinating programmes, students' hostel wardenship. Some of the teachers (i.e. T2, T11, T14) reported that encouragement on the part of management is enough to get involved in TR. For instance, T2 reported, 'I think just appreciation, recognition, encouragement, respect are sufficient to make teachers do TR'. Similarly, T11 stated, 'management's result-centric approach does not let us engage in research; we are supposed to engage in teaching and assessment only'. Finally, T14 complained about 'management's unsupportive attitude with respect to providing facilities, i.e. electronic resources and training, enabling teachers to conduct research'.

\section{Monetary and Logistic Factors}

In addition to that, a number of participants (i.e. T3, T4, T5, T6, T7, T14) expressed monetary benefits as the main incentive for them to engage in TR. For instance, T7 candidly admitted to have never done TR because of his desire to earn extra money by conducting extra classes. His answer is worth-quoting as, 'we are bound to do extra classes in order to get extra remuneration'. The quote explicitly shows that his enormous workload was due to his desire to earn extra remuneration for extra classes. Thus, in response to what incentives he needs to 


\section{HASSAN SYED}

conduct research, T7 replied, 'management should offer packages [financial benefits] to those who want to do research'.

Also, the staggering difference between the senior permanent faculty and junior ad-hoc/contractual faculty also affected teachers' motivation to engage in research. For instance, T6 expressed his sense of lower monetary gains than the senior faculty in these word: 'the permanent faculty gets between 70 and 80 thousands (PKR=Pakistani rupees), whereas we get a meagre 12 thousands (PKR). They have job security, whereas we are on a contract and can be dismissed whenever the management decides as such'. Similarly, T4 specifically mentioned financial benefits as an important incentive. He noted, 'first of all, the salary of us contract teachers should be increased'. T5 also regarded 'money as well as specific equipment, and time liberty' as necessary incentive for him to conduct CR.

Participants also indicated a lack of logistics, such as proper offices, laptops and electronic resources as a major impediment to TR. They expressed their desire for logistic support on the part of authorities For instance, T3 reported 'we should be provided offices, where we can work on research and discuss problems with the students'; similarly, T14 mentioned that teachers 'should be provided with laptops as well as internet facility to make use of modern technology to keep ourselves updated about the state-of-the-art research in language teaching'. Most interestingly, for T13, material incentives were not a strong incentive for classroom research. According to her, 'a teacher ought to be self-motivated to engage in CR'.

\section{Workload}

Heavy workload also emerged as a strong factor impeding teachers' research engagement. T6 reported that junior faculty was assigned too many courses in a semester. According to him, he had 21 contact-hours/teaching hours a week during the current semester. T7, however, reported an incredibly higher number of contact-hours (32 hours) as the reason he could not engage in research. Similarly, T9 and T13 considered reduction of workload as an incentive for them to do research.

Language teacher's workload is a major issue, so this may be reduced...(T9) First of all, there should be minimum workload. (T13)

\section{Large Classes}

Finally, some of the participants, i.e. T4, T8 and T13, mentioned large classes to be an impediment to teachers' CR. For instance, T4 stated, 'it is difficult to conduct research in a class of 40-50 students'. T14's response is worth quoting,

I do have four classes with four different subjects along with 150+ (One fifty plus) students per class. We get limited opportunities in large classes to identify problems of the students.

\section{Discussion}

The current study aimed to explore the factors that motivate or prevent teachers to engage in TR in four public sector universities in the Sindh province of Pakistan. The study showed that a majority of participants regarded research to be an activity aimed at finding something new, while others considered research to be analogous to scientific inquiry conducted in a lab. Most notably, while participants displayed awareness of and interest in solving students' problems, their engagement in TR seemed to be limited as well as occasional. For example, while some participants claimed to have engaged in research whenever [my italics] a problem arose in the class, a majority seemed to have conducted it sometime in the past, recent or distant. Furthermore, their research also lacked systematicity and rigor. Thus, the conceptions as well as the research activity did not strictly fit into the definition of TR as a 'systematic self-study that seeks positive impact and is made public' (Sanchez \& Borg, 2015, p. 185). When asked what methods they use to investigate and solve classroom-specific problems, most of the participants mentioned only two methods, such as observations and reflections. Whether they were aware of other methods, such as questionnaires, interviews/individual meetings with students, and etc., was not reflected in their responses. This reflects lack of knowledge of research and research skills among participants. 
These findings are in partial consonance with previous research in the sense that while participants expressed willingness to address classroom related issues through observations and reflections, however, they did not use the data to solve the issue (Alison \& Carey, 2007; Borg, 2007; Borg \& Sanchez, 2015).

Most interestingly, while a few participants were intrinsically motivation to conduct research in order to solve students' problems and improve their own teaching skills, majority of them showed disinterest in TR and held exogenous factors, including academic culture, management's attitude, senior faculty's attitude, excessive workload, lack of incentives, and large classes, as responsible for it. The role of academic culture appeared as a recurrent theme in the findings. It indicates a deep and subtle impact it had on teachers' classroom practices as well as on them as teachers. Most of the participants unequivocally reported that research is not discussed in their respective institutions. Contractual teachers reported that permanent faculty mostly indulge in legpulling, lobbying and petty politics. They also reported that the attitude of senior faculty towards their juniors was discouraging and disparaging. Although the senior faculty possessed research skills, they were less willing to guide the juniors in research. What is strange is that some of the participants who belonged to senior faculty also admitted to the unequal power relations between senior and junior faculty. Thus, the present study contributes to literature by highlighting the imperious and paranoiac attitude of senior faculty as a barrier in a Pakistani context.

Furthermore, teachers expressed anomalous views about the role of management in supporting or impeding TR. Some of the teachers said that the management does not favour or facilitate teachers' research; rather, it overburdens them with workload, involving teaching and administrative jobs, while others regarded the management to be supportive, and instead, held themselves responsible for not engaging in research. This ambivalence on the part of participants reveals, among other things, the dualistic attitude of university authorities/management towards the idea of TR. Also, these incongruous responses also suggest that management pays lip-service to TR but not encourage it practically, for instance, by offering them incentives or lessening their workload. It is also noteworthy that teachers' performance in all the four institutions was measured by the number of chapters covered and the score of their students in exams. The inconsistent attitude of management is also congruent with previous research (Borg \& Alshumaimeri, 2012; Nadeem, 2011).

Also, workload or syllabus completion acts like a spectre haunting the EL teachers all the time. While in previous research teachers were reported to have 18-20 hours of workload per week (Atay, 2008), teachers in the present study reported on an even higher workload (32 hours/week). Higher workload, in turn, was also found to be responsible for lack of time. This finding is consistent with previous studies in which the lack of time was cited as the most common factor (Atay, 2008; Borg, 2009; Worral, 2004). Besides workload, large classes with a disproportionate number of students was also highlighted by a few students. This seems to have been corroborated by previous studies in the context of Pakistan (Bughio, 2013; Shamim, 1996). Teachers demanded a few incentives in order for them to do TR, including rise in salaries, and availability of resources, such as books, magazines, offices, laptops and offices. The lack of these incentives explain the lack of motivation and, consequently, a moderate engagement of teachers in TR. This information reinforces the need for providing incentives to enhance teachers' motivation to engage in TR. Some of the findings of the current study, such as dubious role of management, lack of research skills, time and resources, are consistent with previous research (Borg \& Alshumaimeri, 2012; McDonough, 2006; Moore, 2011); however, a number of findings, such as unprofessional attitude of teachers, imperious attitude of senior faculty, excessive teaching hours and large classes, were unique to the context of the current study.

\section{Conclusion}

This study was inspired by the increasing popularity of TR and specifically by the dearth of studies into English language (EL) teachers' TR in universities in the Sindh province of Pakistan. The aim of this study was to explore the factors which affect EL teachers' research into classroom-specific problems. Based on semi-structured interviews with fifteen EL practitioners in four public sector universities, the study showed that a majority of EL teachers were only modestly familiar with and interested in conducting TR on their own. The main factors that affected TR included lack of familiarity with TR, academic culture, management's attitude, lack of support from senior faculty, lack of incentives, lack of time and logistics, and large classes. 


\section{HASSAN SYED}

The findings of this study show that TR cannot become a classroom reality until major changes are made at i) macro-level, i.e. in educational policy, ii) micro-level, i.e. institutional/university-level, and iii) individual level. At the policy-level, i) action research ought to be made an integral part of teacher education programs whereby teachers are trained into conducting TR. ii) At a university-level, management's dichotomous conceptions regarding the role of teacher and researcher need to change by an top-down intervention the policy level. However, merely a change in policy might not convince management at a university level to provide teachers with more autonomy with regard to addressing classroom-specific issues by intervening through TR. Awareness campaigns and workshops on TR are required to inform the management of the potential implications of TR for the improvement of teachers' professional growth, and enrichment of students' learning experiences.

In addition, unsupportive or indifferent attitude of research-trained faculty towards their novice colleagues can be addressed by management's encouragement and incentivising mentoring faculty interested in TR. While changes in policy and management's attitude are necessary, what is even more essential is the teachers' motivation and willingness to engage in TR. Therefore, iii) at an individual level, teachers' concerns regarding judicious workload, large classes and monetary incentives ought to be addressed by the management and government (Halai, 2011; Kasi, 2007; Nadeem, 2011). In other words, there needs to be a balance between topdown institutional support and a bottom-up teacher motivation for TR to be a sustainable classroom practice on the part of language teachers (Tuyan, 2018). In a Pakistani context, the findings of this study can help HEC Pakistan in accomplishing its Vision-20254; that is, promoting constructive research culture in academia and increase the production of research aimed at solving local issues.

The results of the current study cannot be generalised due to a small sample size (nearly $25 \%$ of the total workforce) of EL teachers of the four universities in the region. However, the aim of the study was not to generalise the findings but to analyse teachers' perceptions of research, and explore the factors preventing teachers from engaging in research in order to contribute to research aiming it exploring the feasibility of TR in a university context, and secondly to inform teacher educators and policy-makers. Besides, while this study could examine the perceptions of EL teachers from four public sector universities, future studies may explore the factors in other public and private sector universities to get a better understanding of facilitating and debilitating factors affecting TR in Pakistan. Also, future studies must also focus on exploring strategies for integrating research with teachers' classroom practices.

\section{References}

Allison, D., \& Carey, J. (2007). What do university language teachers say about language teaching research? TESL Canada Journal, 24(2), 61-81. https://doi.org/10.18806/tesl.v24i2.139

Allwright, D. (2005). Developing principles for practitioner research: The case of exploratory practice. The Modern Language Journal, 89(3), 353-366. https://doi.org/10.1111/j.1540-4781.2005.00310.x

Atay, D. (2008). Teacher research for professional development. ELT Journal, 62(2), 139-147. https://doi. org/10.1093/elt/ccl053

Barkhuizen, B., Burns, A., Dikilitaş, K., \& Wyatt, M. (2018). Empowering teacher researchers, empowering learners. IATEFL

Borg, S. (2006). Conditions for teacher research. English Language Forum, 6, 22-27.

Borg, S. (2007). Research engagement in English language teaching. Teaching and Teacher Education, 23, 731747. https://doi.org/10.1017/S0261444810000170

Borg, S. (2009). English language teachers' conceptions of research. Applied Linguistics, 30(3), 358-388. https:// doi.org/10.1093/applin/amp007

Borg, S., \& Alshumaimeri, Y. (2012). University teacher educators' research engagement: Perspectives from Saudi Arabia. Teaching and Teacher Education, 28, 347-356. https://doi.org/10.1016/j.tate.2011.10.011

Borg, S., \& Sanchez, H. S. (2015). Key issues in doing and supporting language teacher research. In S. Borg, \& H. S. Sanchez, International Perspectives on Teacher Research (pp. 1-12). Palgrave Macmillan.

Bughio, F. A. (2013). Improving English language teaching in large classes at University level in Pakistan [Unpublished doctoral dissertationб University of Sussex]. http://sro.sussex.

\footnotetext{
${ }_{4}$ Higher Education Commission of Pakistan (2017). Higher Education Commission of Pakistan Vision-2025. https://www.hec.gov.pk/english/HECAnnouncements/Documents/Announcement/HEC-Vision-2025.pdf
} 


\section{FACTORS PREVENTING IN-SERVICE UNIVERSITY ENGLISH LANGUAGE}

ac.uk/45170/

Burns, A. (2005). Action research: An evolving paradigm? Language Teaching, 38(2), 57-74. https://doi. org/10.1017/S0261444805002661

Christenson, M., Slutsky, R., Bendau, S., Covert, J., Dyer, J., Risko, G., \& Johnston, M. (2002). The rocky road of teachers becoming action researchers. Teaching and Teacher Education, 18, 259-272. https://doi.org/10.1016/ S0742-051X(01)00068-3

Cochran-Smith, M., \& Lytle, S. L. (1992). Communities for teacher research: Fringe or forefront? American Journal of Education, 100(3), 298-324. https://www.jstor.org/stable/1085491

Cochran-Smith, M., \& Lytle, S. L., (1993). Inside/Outside: Teacher research and knowledge. Teachers College Press

Cochran-Smith, M., \& Lytle, S.L. (1998). Teacher research: The question that persists. International Journal of Leadership in Education: Theory and Practice, 1(1), 19-36.

Creswell, J. W. (2014). Research design: qualitative, quantitative and mixed methods approaches (4th ed.). Sage.

Everton, T., Galton, M., \& Pell, T. (2000). Teachers' Perspectives on Educational Research: Knowledge and context. Journal of Education for Teaching: International research and pedagogy, 26(2), 167-182. https://doi. org/10.1080/02607470050127081

Gao, X., \& Chow, A. (2012). Primary school English teachers' research engagement. ELT Journal, 66(2), 224-232. https://doi.org/10.1093/elt/ccr046

Halai, N. (2011). How teachers become action researchers in Pakistan: Emerging patterns from a qualitative metasynthesis. Educational Action Research, 19(2), 201-214.

Halai, A. (2015). Teacher education continuum: A case for continuing professional development. In A. Rashid, \& I. Muzaffar's 'Educational Crisis and Reform: Perspectives from South Asia' (pp. 347-381). Oxford University Press.

Mackay, J., Birello, M., \& Xerri, D. (2018). ELT research in action: Bridging the gap between research and classroom practice. IATEFL

Kasi, F. (2010). Collaborative action research: An alternative model for EFL for teacher professional development in Pakistan. The Asian EFL Journal Quarterly, 12(3), 98-117.

Khan, S., Shah, S. M., \& Khan, T. (2018). An investigation of attitudes towards the research activities of university teachers. Bulletin of Educational Research, 40(1), 215-230.

Khurram, B. A. (2018). Promoting learner engagement in a large university-Level ESL class in Pakistan. In K. Kuchah \& F. Shamim's (Eds.), International perspectives on teaching English in difficult circumstances: Contexts, challenges and possibilities' (pp. 73-88). Palgrave Macmillan

Kirkwood, M., \& Christie, D. (2006). The role of teacher research in continuing professional development. British Journal of Educational Studies, 54(4), 429-448. https://doi.org/10.1111/j.1467-8527.2006.00355.x

Levkina, M. (2018). Teaching pronunciation through tasks: Myth or reality? In J. Mackay, M. Birello, \& D. Xerri,'s (Eds.), ELT in Action: Bridging the gap between research and classroom practice (pp. 51-54). IATEFL

Macaro, E. (2003). Second language teachers as a second language classroom researchers. Language Learning Journal, 27, 43-51. https://doi.org/10.1080/09571730385200071

Magos, K. (2012). But I cannot do research: action-research and early childhood teachers. A case study from Greece. Teachers and Teaching: Theory and Practice, 18(3), 331-343. https://doi.org/10.1080/13540602.2012. 629839

McDonough, K. (2006). Action research and the professional development of graduate teaching assistants. The Modern Language Journal, 90(1), 33-47. https://doi.org/10.1111/j.1540-4781.2006.00383.x

Moore, S. (2011). Cambodian English teachers' conceptions of and engagement with research. http://scholar.google.co.uk/scholar?q=Cambodian+English+Teachers\%E2\%80\%99+Conceptions+of+and+Engagement+with\&btnG $=\& h l=e n \& a s \_s d t=0 \% 2 C 5$

Nadeem, M. (2011). Re-searching research culture at higher education. Journal of Research and Reflections in Education, 5(1), 41 -52.

Newby, P. (2010). Research Methods for Education. Pearson Education Limited.

Saglam, A. L. G., \& Dikilitas, K. (2019). Stories by teacher researchers in an online research community. IATEFL.

Sanchez, H., \& Borg, S. (2015). Teacher research: Looking back and moving forward. In S. Borg \& H. S. Sanchez (Eds.), International perspectives on teacher research (pp. 185-193). Palgrave Macmillan.

Sarwar, Z. (2001). Innovations in large classes in Pakistan. TESOL Quarterly, 35(3), 497-500. https://doi. org/10.2307/3588033

Schapper, J., \& Mayson, S. E. (2010). Research-led teaching: Moving from a fractured engagement to a marriage of convenience. Higher Education Research \& Development, 29(6), 641-651. https://doi.org/10.1080/0729436 0.2010 .489236 


\section{HASSAN SYED}

Shkedi, A. (1998). Teachers' attitudes towards research: A challenge for qualitative researchers. International Journal of Qualitative Studies in Education, 11(4), 559-577. https://doi.org/10.1080/095183998236467

Slimani-Rolls, A. (2018). Using exploratory practice to develop teacher research. In S. Etherington \& M. Daubney's (Eds.), Developing as EFL researcher: Stories from the Field (pp. 29-34). IATEFL

Suzuki, N. (2018). How do teacher questions affect students' L2 task performance in EFL classrooms? In J. Mackay, M. Birello \& D. Xerri,'s (Eds.), ELT in Action: Bridging the gap between research and classroom practice (pp. 55-60). IATEFL

Taylor, J. (2007). The teaching-research nexus: A model for institutional management. Higher Education, 54(6), 867-884. https://doi.org/10.1007/s10734-006-9029-1

Tien, F. F. (2000). To what degree does the desire for promotion motivate faculty to perform research? Testing the expectancy theory. Research in Higher Education, 41(6), 723-752. https://doi.org/10.1023/A:1007020721531

Tuyan, S. E. (2018). On the way to achieve sustainability: An evaluative look at a three-year action research program in an ELT context. In G. Barkhuizen, A. Burns, K. Dikilitaş \& M. Wyatt's (Eds.), Empowering teacher researchers, empowering learners (pp. 19-28). IATEFL

Xie, J. (2015). Learning to do teacher research independently: Challenges and solutions. In S. Borg \& H. S. Sanchez's (Eds.), International Perspectives on Teacher Research (pp. 47-56). Palgrave Macmillan.

Worrall, N. (2004). Trying to build a research culture in a school: Trying to find the right questions to ask. Teacher Development, 8(2-3), 137-148. https://doi.org/10.1080/136645304002000020228

Wyatt, M. (2011). Teachers researching their own practice. ELT Journal, 64(4), 417-425. https://doi.org/10.1093/ elt/ccq074 


\section{Appendix 1}

Participants' information

\begin{tabular}{|c|c|c|c|c|c|c|c|c|}
\hline No & $\begin{array}{l}\text { Name/ } \\
\text { Code }\end{array}$ & $\begin{array}{l}\text { Age (in } \\
\text { years) }\end{array}$ & \multicolumn{2}{|c|}{$\begin{array}{c}\text { Qualifications } \\
\text { (B.ED/MA/M.ED/M. } \\
\text { Phil/PhD) }\end{array}$} & $\begin{array}{c}\text { Experience } \\
\text { of ELT at a } \\
\text { university level }\end{array}$ & $\begin{array}{l}\text { Experience } \\
\text { of ELT at a } \\
\text { college level }\end{array}$ & Status & $\begin{array}{l}\text { Monthly } \\
\text { income }\end{array}$ \\
\hline \multirow[t]{6}{*}{ Uni-1 } & $\mathrm{T} 1$ & 45 & \multicolumn{2}{|c|}{ MA (English literature) } & 21 & $\begin{array}{l}\text { Not applicable } \\
\text { (NA) }\end{array}$ & $\begin{array}{l}\text { Senior faculty } \\
\text { with permanent } \\
\text { job }\end{array}$ & $160,000 /-$ \\
\hline & $\mathrm{T} 2$ & 44 & \multicolumn{2}{|c|}{$\begin{array}{l}\text { M.Phil (Linguistics) and } \\
\text { MA (Literature) }\end{array}$} & 16 & NA & $\begin{array}{l}\text { Senior faculty } \\
\text { with permanent } \\
\text { job }\end{array}$ & $140,000 /-$ \\
\hline & $\mathrm{T} 3$ & 31 & \multicolumn{2}{|c|}{$\begin{array}{l}\text { MA (English literature)/ } \\
\text { B.Ed }\end{array}$} & 5 & NA & $\begin{array}{l}\text { Junior faculty } \\
\text { with permanent } \\
\text { Job }\end{array}$ & $80,000 /-$ \\
\hline & $\mathrm{T} 4$ & 31 & \multicolumn{2}{|c|}{ literature/M.Ed } & 4 & NA & $\begin{array}{l}\text { Junior faculty on } \\
\text { contract }\end{array}$ & $12000 /-$ \\
\hline & $\mathrm{T} 5$ & 27 & $\begin{array}{l}\text { Masters in } \\
\text { literature }\end{array}$ & English & 3 & NA & $\begin{array}{l}\text { Junior faculty on } \\
\text { contract }\end{array}$ & $12000 /-$ \\
\hline & T6 & 26 & \multicolumn{2}{|c|}{ Masters in Linguistics } & 4 & NA & $\begin{array}{l}\text { Junior faculty on } \\
\text { contract }\end{array}$ & $12000 /-$ \\
\hline \multirow[t]{5}{*}{ Uni-2 } & $\mathrm{T} 7$ & 42 & $\begin{array}{l}\text { Masters in } \\
\text { literature }\end{array}$ & English & 7 & 12 & $\begin{array}{l}\text { Senior faculty } \\
\text { with permanent } \\
\text { job }\end{array}$ & $80,000 /-$ \\
\hline & $\mathrm{T} 8$ & 40 & $\begin{array}{l}\text { Masters in } \\
\text { literature/M.Ed }\end{array}$ & English & 7 & 11 & $\begin{array}{l}\text { Senior faculty } \\
\text { with permanent } \\
\text { job }\end{array}$ & $80,000 /-$ \\
\hline & T9 & 32 & $\begin{array}{l}\text { Masters in } \\
\text { literature }\end{array}$ & English & 5 & 4 & $\begin{array}{l}\text { Senior faculty } \\
\text { with permanent } \\
\text { job }\end{array}$ & $80,000 /-$ \\
\hline & $\mathrm{T} 10$ & 33 & \multicolumn{2}{|c|}{ Masters in Linguistics } & 3 & NA & $\begin{array}{l}\text { Junior faculty } \\
\text { with permanent } \\
\text { job }\end{array}$ & $80,000 /-$ \\
\hline & $\mathrm{T} 11$ & 29 & $\begin{array}{l}\text { Masters in } \\
\text { literature }\end{array}$ & English & 5 & NA & $\begin{array}{l}\text { Junior faculty } \\
\text { with permanent } \\
\text { job }\end{array}$ & $80,000 /-$ \\
\hline \multirow[t]{3}{*}{ Uni-3 } & T12 & 28 & $\begin{array}{l}\text { Masters in } \\
\text { literature }\end{array}$ & English & 4 & NA & $\begin{array}{l}\text { Junior faculty on } \\
\text { contract }\end{array}$ & $80,000 /-$ \\
\hline & $\mathrm{T} 13$ & 29 & $\begin{array}{l}\text { Masters in } \\
\text { literature }\end{array}$ & English & 4 & NA & $\begin{array}{l}\text { Junior faculty on } \\
\text { contract }\end{array}$ & $80,000 /-$ \\
\hline & $\mathrm{T} 14$ & 28 & $\begin{array}{l}\text { Masters in } \\
\text { literature }\end{array}$ & English & 4 & NA & $\begin{array}{l}\text { Junior faculty on } \\
\text { contract }\end{array}$ & $80,000 /-$ \\
\hline Uni-4 & $\mathrm{T} 15$ & 30 & $\begin{array}{l}\text { Masters in } \\
\text { literature }\end{array}$ & English & 4 & 4 & $\begin{array}{l}\text { Junior faculty } \\
\text { with permanent } \\
\text { job }\end{array}$ & $80,000 /-$ \\
\hline
\end{tabular}

